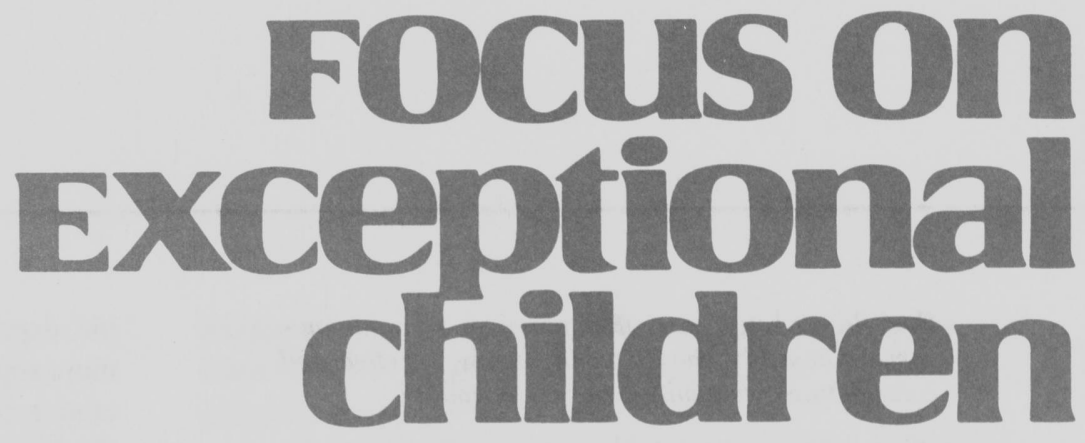

\title{
A Curriculum Development Process for Inclusive Classrooms
}

\author{
Jennifer York, Mary Beth Doyle, and Robi Kronberg
}

How can her functional needs be met? I thought life skills were important.

How am I supposed to meet his unique learning needs when I have 35 other students in my class?

What should I expect? Do I treat her the same as the other kids?

Wouldn't her needs be better met somewhere else with someone who is specially trained?

We don't teach that here. She needs to go to special ed.

These are just some of the comments frequently heard in schools that are moving toward a more inclusive approach to education. More and more students who previously spent most or all of their school days in self-contained special education classrooms now are classmates with peers who are not labeled. In addition, removal from general education continues to be questioned for students classified as mildly disabled who traditionally have spent just small portions of the school day separated from peers (Lipsky \& Gartner, 1989; Stainback, Stainback, \& Forest, 1989; Will, 1986; Ysseldyke \& Algozzine, 1990; Ysseldyke, Algozzine, \& Thurlow, 1992). This movement, referred to as inclusive education (Brown et al., 1989; Lipsky \& Gartner, 1989; McDonnell \& Hardman, 1989), is in part responsible for an escalating dialogue about how to best meet the curricular and instructional needs of students with disabilities. Not surprisingly, it also has generated a number of issues about curricular and instructional practices for all students, not just those with identified disabilities. Increased heterogeneity in classrooms raises many gray issues that previously were dealt with by removing "the problem"-i.e., the child who did not succeed by traditional methods or from the standard curriculum scope, sequence, and pace. Some of these issues surface in the following comments educators frequently express:

Given that we cannot teach all kids everything that is known or that they need to know, what is most important and relevant for an individual student?

What is the real purpose of grades and does our A-F system accomplish this purpose?

When do we decide to emphasize building capacities as much as remediating deficits, many of which are not successfully remediated?

What is most important for secondary students? And-about these Carnegie units-how appropriate is that standard for kids who are really struggling?

Jennifer York is an assistant professor and Mary Beth Doyle and Robi Kronberg are project coordinators in the Department of Educational Psychology and the Institute on Community Integration at the University of Minnesota, Minneapolis.

(c) Love Publishing Company, 1992. 
How do we align curricular practices with our outcome statements about students being effective and contributing community members as adults?

What is fair and equitable in terms of accommodations? If I make an exception for one student, don't I have to make it for all?

Will changing (lowering) the standards for some result in diminished learning for all?

Perhaps the only clear conclusion that can be drawn from the range of issues that is surfacing is that both general and special education are at a critical crossroad for determining what schools should be about for all students and how to realign curricular and instructional practices accordingly. Our dual system of education (special education and general education) has outlived its once constructive purpose (Ainscow, 1991; Skrtic, 1988, 1991; Stainback, Stainback, \& Forest, 1989). Ysseldyke, Algozzine, and Thurlow (1992) make an analogy that reform in general education and special education is similar to the parallel play of young children. Drawing from this analogy, the separateness of the systems may have been developmentally appropriate and necessary, but it is time to move forward together using the resources (peo-

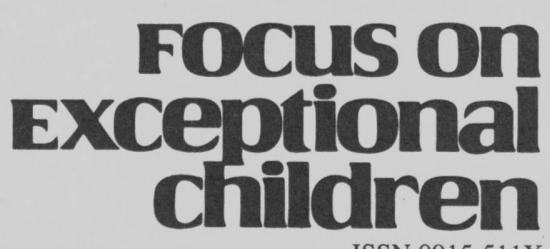

ISSN 0015-511X FOCUS ON EXCEPTIONAL CHILDREN (USPS 203-360) is published monthly except June, July, and August as a service to teachers, special educators, curriculum specialists, administrators, and those concerned with the special education of exceptional children. This publication is annotated and indexed by the ERIC Clearinghouse on Handicapped and Gifted Children for publication in the monthly Current Index to Journals in Education (CIJE) and the quarterly index, Exceptional Children Education Resources (ECER). It is also available in microfilm from Xerox University Microfilms, Ann Arbor, MI. Subscription rates: Individual, \$27 per year; institutions, \$36 per year. Copyright (c) 1992, Love Publishing Company. All rights reserved. Reproduction in whole or part without written permission is prohibited. Printed in the United States of America. Second class postage is paid at Denver, Colorado. POSTMASTER: Send address changes to:

Love Publishing Company

Executive and Editorial Office

1777 South Bellaire Street

Denver, Colorado 80222

Telephone (303) 757-2579

Edward L. Meyen

University of Kansas
Glenn A. Vergason Georgia State University

Richard J. Whelan

University of Kansas Medical Center

Stanley F. Love

Publisher
Holly T. Rumpler Senior Editor ple, expertise, facilities, money) within each system to create more sophisticated forms of interaction, comparable to cooperative play. The underlying causes giving rise to many of the reform initiatives are not exclusive to one system or the other but provide more evidence that yet another shared agenda for general and special education is the redesign of curricular and instructional practices so all students learn what is and will be most important to them in their current and future lives (York, 1991).

This issue of Focus on Exceptional Children focuses on ways to meet the needs of students with disabilities in inclusive classrooms, although many of the strategies presented are useful for students without disability labels as well. Specific purposes are: (a) to provide a broad definition of inclusion as the overarching framework for the curriculum discussion that follows, (b) to discuss some ways to think about curriculum related to inclusive education, (c) to present a process of curriculum development that will assist teams in moving students with disabilities from primarily self-contained classrooms to inclusive classrooms with classmates without disabilities, and (d) to provide specific curricular strategies and tools to assist in the curriculum development process for students with moderate to severe disabilities.

\section{INCLUSION DEFINED}

Educators and parents often ask what "inclusion" means. Critical aspects of inclusion are: attending the same schools as siblings and neighbors, being in general education classrooms with chronological age-appropriate classmates, having individualized and relevant learning objectives, and being provided with the necessary support (e.g., special education and related services) to learn (Rainforth, York, \& Macdonald, 1992; Taylor, 1988). Inclusion does not mean that students must spend every minute of the school day in general education classes (no student should), that students never receive small-group or individualized instruction, or that students are in general education classes to learn the core curriculum only.

To become the basis of daily thought and action, inclusion, like any value, must be personal and relevant for each individual. We ask people to define inclusion for themselves. "What does it mean to be fully included in a community? How does it feel?" Among the words offered in response are:

$\square$ opportunities
$\square$ contributing
$\square$ participating
$\square$ respected
$\square$ accepted
$\square$ valued
$\square$ friends

$\square$ belonging
$\square$ making choices
$\square$ being needed
$\square$ cooperating
$\square$ useful
$\square$ happy
$\square$ freedom




\section{$\square$ successful \\ $\square$ secure \\ $\square$ confident \\ $\square$ taking risks}

By way of contrast, we ask, "What does it mean to be excluded from a community? How does it feel?" Responses include:

$\square$ rejection
$\square$ discriminated against
$\square$ denied participation
$\square$ weird
$\square$ alone
$\square$ angry
$\square$ sad
$\square$ afraid

$\square$ viewed as different
$\square$ denied opportunity
$\square$ ignored
$\square$ inferior
$\square$ powerless
$\square$ resentful
$\square$ frustrated
$\square$ depressed

Finally, we ask, "If you were excluded, how would you act?" Responses include:

\section{$\square$ aggressive \\ $\square$ spiteful \\ $\square$ rebellious}

These responses reveal what inclusion really means and how essential it is for all of us.

Specific decisions-regarding, How much time is spent where? What's the curriculum? Who provides support?vary across contexts and change over time. Most important, a personal and collective commitment is made to create inclusive, equitable school communities as one means for realizing inclusive, equitable communities at large. As the value of inclusiveness becomes foremost in the minds and hearts of individual community members, it becomes a fundamental base for daily decisions and choices in life-personally and professionally.

Another way to connect more personally with the meaning and purpose of inclusion is to think specifically about what being included in family life means. Doug Biklen (1992) interviewed families whose children are fully included in their respective families and who have disability labels. A number of common themes emerged:

$\square$ Recognizing that people without special training can raise children with disabilities

avoiding labels

Making inclusion unconditional

$\square$ Accepting diversity

$\square$ Identifying individual gifts

Maintaining equal status

$\checkmark$ Providing constant inclusion

$\square$ Considering the future

$\square$ Building relationships

$\square$ Seeking adequate resources

$\square$ Sharing stories

Biklen goes on to discuss how to extend the lessons learned from inclusive families to schools committed to establishing inclusive communities.

As each individual's personal vision of inclusion clarifies, implementing inclusive educational practices becomes real and meaningful. Without this understanding, the strategies, tools, and forms presented in this article, for example, become only an academic exercise, another set of strategies and procedures to follow. Unless implementors internalize the underlying values, even the best written IEP will not translate into practice and interventionists will become mere recipe followers.

\section{A NEW WAY OF THINKING ABOUT CURRICULUM}

Curriculum is defined by Webster's New World Dictionary (1990, p. 149) as "a course of study in a school." What do students study or learn about in schools? Certainly students need to learn basic and foundational skills: reading, writing, math, and thinking. They need to apply these skills to the natural, environmental, and social cultures around them. They also learn about life, at least in subtle ways. They learn either explicitly or implicitly about being responsible for themselves and their decisions in life, about relationships, and about what does and does not work in terms of being a community. In school, students learn culturally valued norms, attitudes, and skills.

Conceptualized broadly, therefore, curriculum can be thought of as everything children learn in school. Every time an adult interacts with a child or a group of children, those children learn about normed and valued ways of interacting in the school culture. For the value of inclusive community to become operationalized as a reality in schools, the curriculum must include specific attention toward this outcome.

Designing a curriculum for students with disabilities, and probably for all students, can be approached by thinking about learning outcomes in three non-mutually exclusive areas:

$\square$ Learning to be part of a community

$\square$ Learning skills that are useful across contexts

Learning skills that are specific to the respective curricular area that defines the class period

Opportunities are available to address these learning outcomes in most school and classroom environments.

1. To teach children how to be part of a community requires that teachers, first, recognize that the classroom is a community and, second, commit to taking advantage of this opportunity, realizing its importance for all students (SaponShevin, 1990; Schaps \& Solomon, 1990; Snow, 1991). This forms the basis for teaching all students about interperson- 
ally effective means of interaction, rights and responsibilities of community membership, and specific values, attitudes, and skills that make communities work. Ford, Davern, and Schnorr (1991) indicate that this aspect of curriculum frequently is implicit, "the informal lessons that students learn from the classroom environment" (p. 60).

As evidenced in many school districts' mission statements, effective community membership and participation increasingly is articulated as an important outcome of public education. To achieve this outcome, words in a mission statement have to be translated to an explicit base of daily practice, teaching, and learning in schools: Including students with disabilities is one vehicle for bringing this important focus to schools and classrooms ultimately for the benefit of all students.

2. To operationalize the second cluster of learning outcomes (skills and competencies that are useful across contexts), a construct that has proven most useful is based on research by Brown, Evans, Weed, and Owen (1987). They identified nine components that are part of most daily routines. The four sequential components are: initiating, preparing, participating in the core of the routine, and terminating. The five components interwoven during daily routines are: communicating, socializing, solving problems, monitoring quality, and tempo. To this list of interwoven components, positioning and movement have been added by Rainforth, York, and Macdonald (1992).

Generalization across contexts is one of the most difficult aspects of learning. Direct instructional focus on components or skills required regardless of context or circumstance is perhaps the best way to ensure relevance and application by students, especially those with cognitive disabilities (Brown et al., 1979; Ford et al., 1989; Stainback \& Stainback, 1991). One of the tools presented later in this issue (Figure 7) identifies skills required across contexts, specifically in many general education classes. IEP objectives and direct instruction targeting these competencies are part of providing an educational program that will be a solid foundation for participation in community life.

3. The core curriculum in specific general education classes (e.g., language arts, science, home economics) can provide learning opportunities relevant to the unique needs of students with disabilities in at least two ways. First, a student may have learning needs in the core curricular domain. In math class, for example, a student may learn applied math skills related to managing personal finances or shopping. In reading class, a student may learn to look at and enjoy visually interesting reading materials or listen while others read aloud. Second, a core curricular area may spark a special interest to pursue vocationally or avocationally. In earth science class, for example, a student may become interested in geography or rocks, which may lead to expanded leisure pursuits in this area.
The school community (classrooms, other places in and around school grounds, and the community at large) presents a wide array of opportunities for students to learn important and individually relevant skills, attitudes, and values for life. The remainder of this issue presents a process for putting into practice an individualized curriculum that addresses these learning outcomes.

\section{A PROCESS FOR CURRICULUM DEVELOPMENT AND IMPLEMENTATION}

The decision to move toward designing and implementing an inclusive education for students with disabilities is, for most educators, the first of many steps on a new journey. For a student's reality to reflect the descriptors of inclusion presented earlier in this issue, efforts must extend far beyond mere physical presence in classrooms. Proximity is a necessary but insufficient condition for inclusion (Stainback \& Stainback, 1991; Wang, 1992). Achieving an inclusive reality in classrooms requires ongoing reflection and subsequent action. The work of designing the curriculum is never done. Figuring out what is most important for students to learn and how to most effectively teach it is an ongoing process.

The curriculum development process presented here focuses most specifically on students with disabilities. Many of the strategies, activities, and tools, however, have applications for students without disabilities as well. In early inclusion efforts many general educators clearly were uncomfortable spending so much time on the needs of one student with disabilities when they were responsible for addressing the needs of 30 or more students. Additional planning time was not easily accessible nor viewed as equitable.

Through our involvement in inclusive classrooms, we have seen (and heard from general education classroom teachers) that many of the strategies used to increase the social and curricular inclusion of students with disabilities are directly relevant to and supportive of many students without disability labels. These learnings from initial inclusion efforts have resulted in broader thinking related to supporting the needs of all students in addition to providing specific support for students with disabilities. By adopting this orientation, the presence and participation of special educators and support personnel (e.g., related services professionals, instructional assistants) frequently are more welcomed, accepted, and valued in general education classrooms. Contributions of the "special education system" become more evident to general educators, which assists in the development of mutually beneficial partnerships. In effect, all educators join to meet the needs of and care about all students in a school community.

In our partnerships with general and special educators who are developing curricular, instructional, and teamwork prac- 
tices aligned with the value of inclusiveness, many schools, classrooms, and teachers identified similar pressing curricular issues early in the move from mostly self-contained to more inclusive settings, as well as the issues and needs more reasonably and effectively addressed later in the process. In earlier writing about curriculum development for inclusive classrooms, the starting point was to develop a future vision of an inclusive community life for a student (Vandercook, York, \& Forest, 1989; York \& Vandercook, 1991). From this vision, the team approximated a backward chaining process to decide what made most sense for current curricular attention at school.

Working backward from a vision seemed like a logical way to proceed. In practice, however, envisioning a desirable future and maximizing the use of information generated worked more effectively later in the curriculum development process. Frequently, team members were new to curriculum development for inclusive settings and students previously had not been included in general education settings. This resulted in more immediate needs centered on getting to know and be comfortable with the student and learning how he or she participates in an inclusive classroom setting.

The curriculum development process for inclusive classrooms is organized into four "rounds" (see Figure 1).

1. Before students move to new and more inclusive settings, teams engage in a number of preparatory activities to foster a smooth transition.

2. During the first few weeks a student is in the more inclusive setting, team members promote a sense of community among classmates and learn about how the student with disabilities functions in the new classroom.

3. Once the student, classmates, and adult team members get to know one another and have a somewhat common experience base in the inclusive setting, they can collectively envision a desirable future of inclusive community life.

4. With a shared understanding of current abilities and a desirable future, team members decide how to maximize the relevance of current curricular and instructional opportunities. Curricular priorities are reflected in a weekly schedule and specific learning outcomes targeted for each class or other learning environment.

Although necessarily presented as a linear process, in reality this curriculum development process is more circular and integrated, especially in the later rounds.

Round 1: Planning the transition. Design and implementation of a supportive transition process can benefit all students, not just those with disabilities. Defined here, transition refers to the movement between educational settings (e.g., movement from kindergarten to first grade, from ele-

\section{Process of Curriculum Development for Inclusive Classrooms}

Round 1: Planning the transition

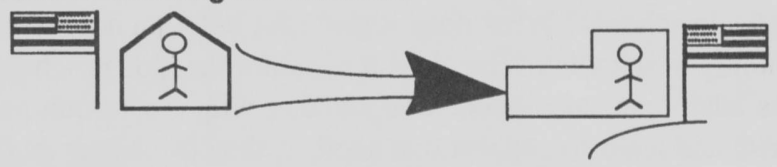

Round 2: Taking the plunge...determining needs in context

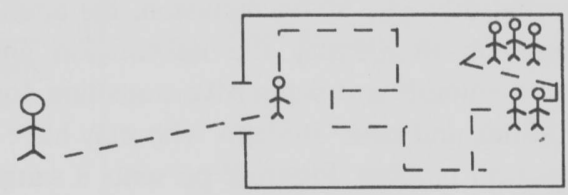

Round 3: Envisioning a desirable future

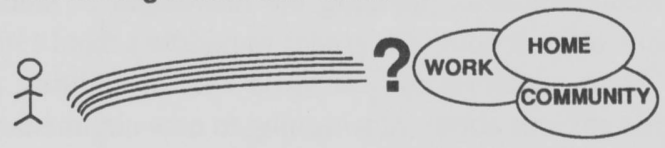

Round 4: Bringing it together and moving forward

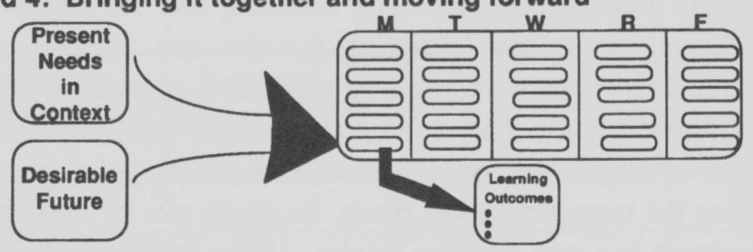

FIGURE 1

Process of Curriculum Development for Inclusive Classrooms

mentary school to middle school, or from middle school to high school) and the respective activities, people, and expectations within the settings. Student-centered outcomes of transition planning include:

$\square$ Movement between educational settings with a feeling of safety, belonging, and support

Movement between educational settings with continuity of programming

- Establishment or maintenance of social connections with peers during and after the transition

Establishment of some degree of familiarity with the new environment

Achieving these outcomes requires collaboration among sending and receiving general and special educators. Usually during the spring before a fall transition, individuals from the sending and receiving educational settings (schools, grades) are identified as representatives on a planning team (Davern et al., 1990; LeRoy, England, \& Osbeck, 1992). 
Adult team members may need to discuss what inclusion is and why it is important. Questions might include: How does our discussion of what inclusion and exclusion mean relate to what our schools are about? How does this relate to our roles in schools? What does it mean for us as an adult community in schools? What does it mean for the kids in school? As adult team members come together with a common purpose and learn to support one another, they can better facilitate the learning and growing of the students in schools.

After initial dialogue about inclusion, the adult planning team moves on to identify the information and actions needed for a smooth and supportive transition for students with disabilities and other students who may have difficulty in the transition process. Figure 2 presents a sample transition planning process developed by a team of general and special educators planning the movement of students from elementary school (4th grade) to middle school (5th grade).

Many students, not just those with disabilities, are somewhat anxious about transitioning to new circumstances. New environments represent many unknowns about people, routines, and expectations. All students can be involved in learning about and planning for the new circumstances. Transitions can be especially difficult for students who do not have friends. The sending team should facilitate at least a few connections between the student and his or her peers before the transition takes place. Students can be tremendous support for one another (Kohn, 1991; Stainback \& Stainback, 1992).

The activity outlined in Figure 3 shows one way that students can be included to support and involve one another in the transition process. This activity also presents an opportunity for students to raise concerns that may turn out to be myths. For example: Have any 5 th graders ever gotten lost? Is there really a pool in the middle school and everyone has to swim for 20 minutes without stopping? What happens if I can't open my locker? By the end of the student support team session, the students will have identified several ways to support themselves and classmates or students previously separated during the transition. The adult facilitator involved helps the students implement the strategies. Figure 3 is a sample student support team activity.

Some students, such as those with disabilities, have unique needs and may require more than the usual type and amount of support. Information about these students that can assist adult team members in planning a smooth transition may include highlights of the students' strengths, gifts, and abilities, and his/her areas of need (including health and management). Also helpful is a brief description of instructional strategies that have been effective. This information usually is gathered by members of the sending team. A sample form used to collect this information is presented in Figure 4 . Although used predominantly with students with dis- abilities, some elementary schools complete one for each student who moves to middle school.

The next step in planning the transition for students with disabilities is to outline a general plan for the first few weeks of school. The receiving general educator(s), sending and receiving special educators or other support personnel, and a parent usually are involved in this activity. A sample form to guide this activity is presented in Figure 5. First the general educator outlines a daily or weekly schedule, or both, including times, locations, activities, and instructional format of the regular class outline (Rainforth, York, \& Macdonald, 1992).

Next, given what is known about the new student, team members discuss how the student might participate in the regular class routine. If they anticipate that the student will require support during any part of the schedule, indicate the type of support to be provided, at least initially (e.g., adapted materials, classmate, paraprofessional). For secondary students who will be in a number of different classes with many different teachers, a separate scheduling form is used for each class. Because many more people are involved and there is much less flexibility at the secondary level, this scheduling and support determination process may have to occur between each classroom teacher and the student's primary support person (e.g., case manager, special educator).

Preparing for the transition also involves developing an action plan. Action plans are necessary to document priorities, track individual responsibilities, and develop timelines for task completion. Life in schools is hectic. An important function of teams is to determine priorities for individual attention, as well as activities that can wait. Action plans document priorities agreed upon by the team. Action plans usually include the following components: What has to be done? Who should do it? By when? Figure 6 presents one example of a transition action plan.

Round 2: Taking the plunge. Spring is a time to plan and prepare; once September rolls around, it's time to "take the plunge." The first several weeks of school are critical in establishing an atmosphere of acceptance and belonging for all students in the classroom community. As articulated by Norman Kunc (1992), the importance of belonging is not a new concept but needs to be rediscussed. In "The Need to Belong: Rediscovering Maslow's Hierarchy of Needs," he states:

In his [Abraham Maslow, 1970] discussion of a hierarchy of human needs, he pointed out that belonging is an essential and prerequisite human need that has to be met before one can ever achieve a sense of self-worth. . . . Maslow stressed that only when we are anchored in community do we develop self-esteem, the need to assure ourselves worthy as individuals. ... Belonging is one of the central pillars that has been missing from our educational structures for a long time. (p. 29) 


\begin{tabular}{|c|c|c|}
\hline WHAT & WHO & BY WHEN \\
\hline \multicolumn{3}{|l|}{ Step 1: Initial information from sending school } \\
\hline \multicolumn{3}{|l|}{$\begin{array}{l}\text { Sending school staff members (regular and special education) fill out } \\
\text { "Student General Information Sheets" and copy "Student Log Notes." }\end{array}$} \\
\hline \multicolumn{3}{|l|}{$\begin{array}{l}\text { Sending and receiving teachers share information regarding student } \\
\text { general information }\end{array}$} \\
\hline \multicolumn{3}{|l|}{ I-team member does follow-up if the forms are not received by [spring date]. } \\
\hline \multicolumn{3}{|l|}{ Step 2: CMS Class placement } \\
\hline \multicolumn{3}{|l|}{$\begin{array}{l}\text { At the grade-level meeting, new students are assigned to classroom teachers, } \\
\text { homerooms, and advisors through input from the observation team, grade- } \\
\text { level teachers, and support staff. Considerations for placement include } \\
\text { individual needs for support and combinations of students within each } \\
\text { classroom and hub (5th and 6th grades). }\end{array}$} \\
\hline \multicolumn{3}{|l|}{$\begin{array}{l}\text { The middle school principal is contacted about new student assignments } \\
\text { for consideration during computer scheduling for all students. }\end{array}$} \\
\hline \multicolumn{3}{|l|}{$\begin{array}{l}\text { Letter is sent home to inform parents of class assignments and let them } \\
\text { know that a transition planning meeting will follow later. A short parent } \\
\text { questionnaire will be sent with the letter. }\end{array}$} \\
\hline \multicolumn{3}{|l|}{ Step 3: Receiving teachers contact sending teachers } \\
\hline \multicolumn{3}{|l|}{ Teachers call the sending school to set up visit. } \\
\hline \multicolumn{3}{|l|}{ Teachers visit sending school to observe student(s). } \\
\hline \multicolumn{3}{|l|}{ Step 4: Students visit future classrooms/school } \\
\hline \multicolumn{3}{|l|}{$\begin{array}{l}\text { Individual students are assigned a middle school buddy (a member of } \\
\text { his/her advisory group) for visits. Social days in advisory and at lunch are } \\
\text { possible visit times. }\end{array}$} \\
\hline \multicolumn{3}{|l|}{ Lunch monitor staff takes on a welcoming role. } \\
\hline \multicolumn{3}{|l|}{ Step 5: Student-centered team meetings for transition } \\
\hline \multicolumn{3}{|l|}{$\begin{array}{l}\text { Individual student teams (some combination of classroom teacher, } \\
\text { special educator, parent, advisor, special teachers, and sending teacher, } \\
\text { and instructional assistant when applcable) meet [in May]. } \\
\text { At the meeting the team: }\end{array}$} \\
\hline \multicolumn{3}{|l|}{$\begin{array}{l}\text { - reviews transition materials ("Student General Information Sheet," } \\
\text { observation forms, etc.) }\end{array}$} \\
\hline \multicolumn{3}{|l|}{$\begin{array}{l}\text { - develops an initial plan for transition (needs assessment, "Classroom } \\
\text { Transition Plan" [optional], rough schedule, curriculum, etc.) }\end{array}$} \\
\hline \multicolumn{3}{|l|}{$\begin{array}{l}\text { - decides on whether an IEP meeting or a periodic review would be the } \\
\text { most appropriate for fall. }\end{array}$} \\
\hline \multicolumn{3}{|l|}{ Step 6: Grade-level team meetings for further planning in spring } \\
\hline \multicolumn{3}{|l|}{ Step 7: Setting dates for IEPs and periodic reviews } \\
\hline $\begin{array}{l}\text { Case managers make contacts and set dates [by November 15] for IEPs } \\
\text { or periodic reviews for individual students [by September 30]. }\end{array}$ & & \\
\hline
\end{tabular}

Source: Adapted from form developed by the Cambridge Middle School Inclusion Team, Minnesota, May 1992. 


\section{ACTIVITY: Planning the Transition \\ MATERIALS/ \\ EQUIPMENT: \\ chart paper, markers, a copy of the general daily schedule for the next year, chairs in a semi-circle}

OBJECTIVE: To plan for the transition to middle school and to identify additional support that might be needed for specific students

SET-UP:

Students seated in semicircle for easy viewing of one another and the facilitator. The student(s) with disabilities are part of the group. Co-facilitation with a member of the sending and the receiving teams is best. The facilitator(s) is positioned in front of the students with chart paper poster to record student responses.

DISCUSSION: 1. All of you will be going to the middle school next year. What do you know about being a 5 th grader at the middle school?

How is it different from 4 th grade here? How is it the same?

What does it look like? What does it feel like? What do you think you'll be expected to do there?

What are some things you might look forward to participating in (e.g., clubs, activities)? Would a visit be helpful? What would you want to see? Whom would you like to talk to?

2. Are there any 4th graders who might need some extra help with the transition? How would you describe (student's name)? What are his/her strengths, gifts, and abilities? What are his/her challenge areas? What kind of help might he/she need?

3. You have come up with a lot of good ideas. What do you think are the most important things to do to get ready to go to middle school?

\section{ACTION PLAN}

\begin{tabular}{|l|l|l|}
\hline ACTIVITY & WHO & WHEN \\
\hline $\begin{array}{l}\text { 1. Students visit the middle school. } \\
\text { Connect with middle school students. }\end{array}$ & & \\
Assign big brothers/sisters for the fall. & & \\
Spend the day with big brother/sister. & & \\
2. Meet the teachers for next year. & & \\
3. Practice lock combinations. & & \\
\hline
\end{tabular}

FIGURE 3

Sample Student Support Team Activity for Planning Transitions

\section{GETTING TO KNOW YOU ... GENERAL STUDENT INFORMATION}

To facilitate the best transition for an individual student to a new school/grade, current team members (at minimum, the classroom teacher and special educator), should fill out this form.

Student:

Current Special Educator:

Future Special Educator: General Educator: General Educator:

1. What do you enjoy about the student?

2. What are some of the student's gifts, can-do behaviors, areas of progress, motivators, and interests?

3. What specific teaching strategies and learning style needs stand out for this student?

4. What are the student's top goal areas, needs, and challenges? (If relevant, comment on behavioral strategies. Especially consider transitions between activities and environments that have proven useful.)

5. What strategies have not worked in the past?

6. Who are some of the student's friends? Will they be able to make the transition together? Will at least two of them be in the same homeroom?

7. Briefly describe some of the ways the student participates in the regular classroom.

8. Please list relevant physical or health information (medications, vision, hearing, motor abilities, chronic health problems, etc.).

FIGURE 4

Sample Form to Document Student-Specific Information for Transitions

Using Maslow's construct, therefore, belonging is the basis for self-acceptance, and esteem becomes the base for achievement and contribution.

During the first few weeks of school, the main focus is on accomplishing the following student-centered outcomes:

- Unconditional membership in the classroom and school community with an understanding of the associated rights and responsibilities

Establishment of friendships and social connections among classmates

- Participation in classroom routines and responsibilities to the best of one's abilities

To accomplish the first outcome, students must be actively involved in understanding and creating a sense of 
DAILY SCHEDULE INCLUSION WORKSHEET

Student:
Sending Team:

Receiving Team:

\begin{tabular}{|l|l|l|l|l|}
\hline Time & Environment/Activities & Structure & Student Activities & $\begin{array}{c}\text { Student Support } \\
\text { (adults, classmates, } \\
\text { materials) }\end{array}$ \\
\hline & & & & \\
\hline & & & & \\
\hline & & & & \\
\hline
\end{tabular}

FIGURE 5

Sample Format for Developing an Initial Individualized Schedule

community in their newly forming classroom. Engaging in a class discussion begins this process. The following questions can be asked to facilitate the discussion:

What does it mean to be a community?

Why is it important for all of us?

$\square$ How do you benefit from being part of a community? What responsibilities do you have?

$\square$ Thinking about our classroom as a community, how should we act toward one another? What should we do together?

If someone is having a bad day, what should the rest of us do?

What do you want our classroom to look like?

- When people visit our classroom, what should we do? What do we want them to do?

At the end of the discussion, students identify priority actions and develop a plan. One follow-up activity could be replacing a traditional set of teacher-generated classroom rules with a student-generated (teacher-facilitated) set of community expectations (York, 1992).

The second student-centered outcome during the first few weeks of school is to promote social connections and friendships among classmates. Usually by the second week of school, teachers know how relationships are developing in the classroom and which children need additional support to establish and maintain effective relationships with peers. If any students, with or without disability labels, are not socially connected with their peers, they can be engaged in a discussion about the importance of friendships and relationships. In small groups or as an entire class, the following can be discussed:

What is a friend?

- How does it feel to have a friend?

How do you act when you have friends?

- How would it feel not to have any friends?

How would you act if you didn't have any friends?

$\square$ Do you think that everyone needs to and wants to have a friend?

$\square$ What can we do for kids who do not have friends? What can they do to help?

The adult facilitator helps the students identify specific priority concerns or issues, leads a discussion about why the problems exist and how they could be addressed, and provides ongoing support throughout the next several months as the students get to know each other. This support might take the form of biweekly lunch meetings to talk about issues arising in developing friendships. Some teachers have a daily class meeting to find out how students are getting along with one another and any other issue of significance the students (or the teacher) bring up. This is another opportunity to make students aware that there are tough issues requiring discussion, common understanding, 


\begin{tabular}{|c|c|c|c|}
\hline ACTIVITY & WHO & WHEN & FOLLOW-UP \\
\hline \multicolumn{4}{|l|}{ Regarding open house at the middle school: } \\
\hline 1. Invite all 4 th graders and their parents. & homeroom teacher & $4 / 10$ & none \\
\hline $\begin{array}{l}\text { 2. Check wheelchair accessibility at the } \\
\text { middle school. }\end{array}$ & Mrs. P & $4 / 5$ & report back \\
\hline \multicolumn{4}{|l|}{ 3. During social studies ask students: } \\
\hline \multicolumn{4}{|l|}{ What sounds exciting about middle school? } \\
\hline $\begin{array}{l}\text { What are your biggest fears about } \\
\text { middle school? }\end{array}$ & S.S teachers & $4 / 15$ & discuss@ @eam meeting \\
\hline $\begin{array}{l}\text { 4. Respond to \#2. Identify any students with } \\
\text { unusually strong fears. }\end{array}$ & 4 th grade team & $4 / 20$ & discuss@ team meeting \\
\hline $\begin{array}{l}\text { 5. Develop a plan of support that includes the } \\
\text { student and a friend taking a trip to the middle } \\
\text { school and talking with middle school students } \\
\text { and teachers. }\end{array}$ & 4 th grade team & $4 / 25$ & discuss@ team meeting \\
\hline 6. Identify if additional follow-up to \#5 is necessary. & & & \\
\hline
\end{tabular}

FIGURE 6

\section{Sample Transition Action Plan}

and action. Basic problem-solving and conflict resolution skills taught at a young age will prove invaluable as students get older and problems become more complex (Johnson \& Johnson, 1991).

The third student-centered outcome for the first few weeks of school is participation in classroom routines and responsibilities. The form provided in Figure 7 has been used to identify strengths and challenges in following classroom routines and in communicating and socializing in the classroom. Most students learn and generalize the skills early in their schooling with little or no direct instruction, but many students with disabilities have to be directly taught these routines in the settings where they will be used (i.e., the general education classrooms). During the second or third week of school, team members use the forms to document student performance in each class. Optimally, data are collected for three or four days to make informed and accurate decisions about specific areas of strength and need. Areas of need that are evident across all classes are identified first. Next, class or context-specific needs are identified. These combined needs provide the basis for developing, validating, or revising IEP objectives.

In addition to specific skills required for participating in routines and enhancing social and communication opportunities, most classrooms have specific tasks to be completed daily or weekly so the classroom will operate smoothly-for example, cleaning the erasers, picking up garbage, passing out papers, running errands, representing class- or grade-level interests at larger school forums. Students share in these responsibilities as a way to learn both personal and collective responsibility in a community. All students participate to some extent in such classroom support activities. For example, Sue wants to pass out papers, but she cannot read. A friend can read off the names and Sue can hand out the papers.

Round 3: Envisioning the future. Many initial inclusive education efforts begin with envisioning a desirable future (O’Brien, Forest, Snow, \& Hasbury, 1989; Vandercook, York, \& Forest, 1989). This was not effective for many students for two reasons. First, many of the team members involved in creating the vision of a desirable future had interacted with the student in segregated contexts only. To envision a desirable future of an inclusive community life was a struggle at best, and impossible at worst, when the reality had been one of exclusion and segregation. Frequently, therefore, the vision was limited to more segregated or existing service options. Second, many of the essential team members (i.e., general educators and classmates without disabilities) had not established relationships with the student prior to envisioning a desirable future. Without knowing the student, participation was minimal.

With a sense of community established, relationships developing, classroom routines in place, and current information about classroom participation obtained, efforts can shift from an exclusive focus on day-to-day accommodation to more directed thought about how desired future outcomes relate to current learning opportunities in inclusive classrooms. Student-centered outcomes for this part of the curriculum development process are:

Reflecting on the student's life thus far

$\square$ Recognizing the student's capacities and challenges 


\begin{tabular}{|llll||}
\hline \hline Student: & KEY: & + & Consistently performs \\
Subject/Class: & $+1-$ & Does some of the time, inconsistent \\
Group Format: & - & Never or rarely \\
& & NO & No opportunity \\
\hline
\end{tabular}

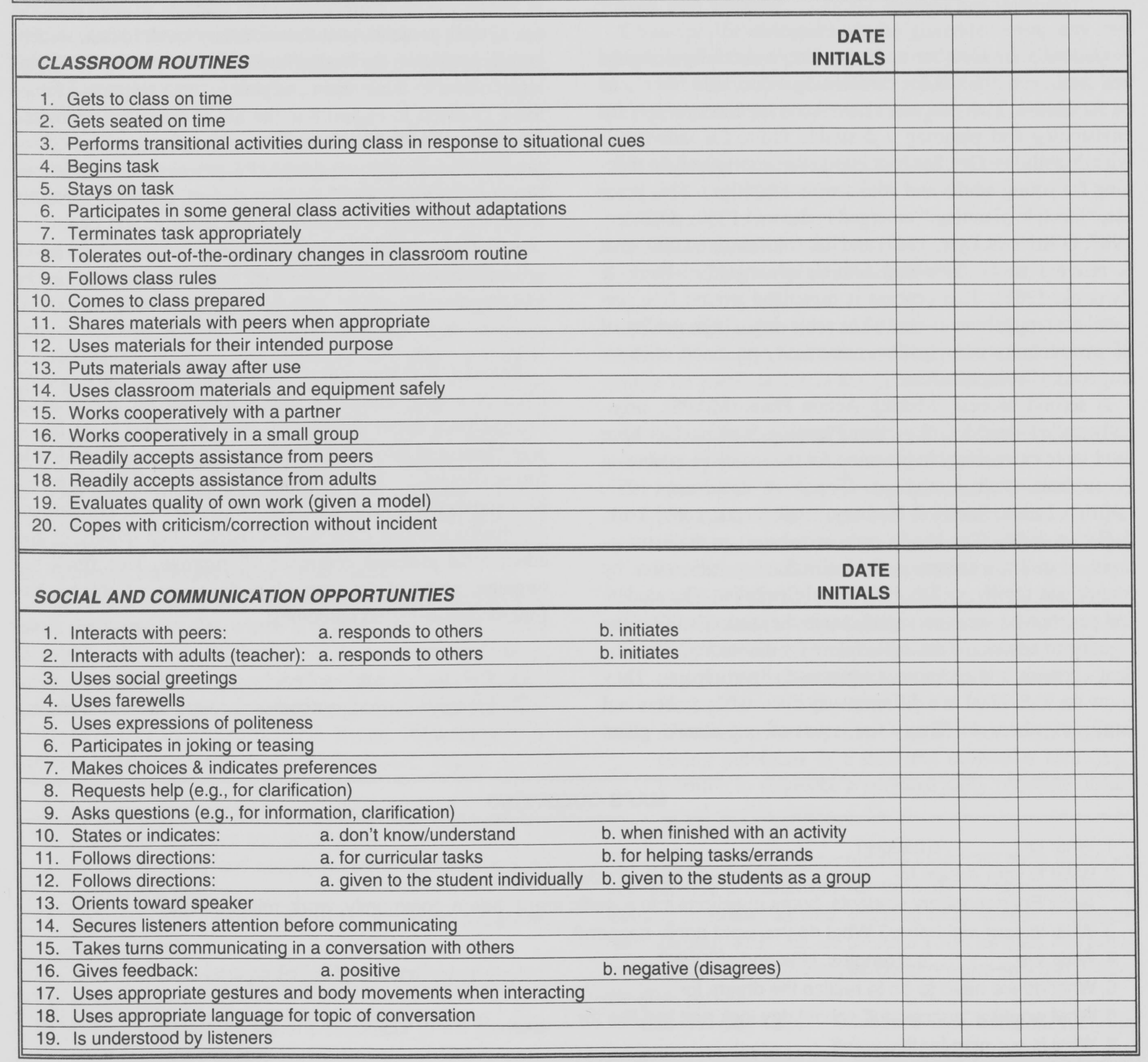

\section{SUGGESTIONS or COMMENTS:}

Source: Adapted from "Instruction in Regular Education Classes for Students with Severe Disabilities: Assessment, Objectives, and Instructional Programs" by C. Macdonald and J. York, 1989, in Strategies for Full Inclusion, edited by J. York, T. Vandercook, and S. Wolff, Minneapolis: University of Minnesota, Institute on Community Integration. 
- Creating a vision for a desirable future community life

$\square$ Determining current priorities that are most likely to lead to the future vision

- Identifying resources (individual, people, contextual, financial) and support

Generally by October or November, a carefully designed and facilitated process for envisioning a desirable future can be facilitated. Two processes have been used extensively for envisioning and planning a desirable future for individuals with disabilities. One has been used more extensively in planning for young adults and adults with disabilities. This process, "lifestyle planning," emerged in the mid 1980s (O'Brien, 1987; O'Brien \& Lyle, 1987) and has since evolved into what is referred to as "personal future's planning" (Mount \& Zwernik, 1988). This process is organized around five personal accomplishments central to achieving a high quality of life: community participation, community presence, choices, respect, and competence.

A second process, Making Action Plans (MAPS), originally called the McGill Action Planning System, has been used more extensively in planning for the inclusive education of students with disabilities (Forest \& Lusthaus, 1987; O'Brien, Forest, Snow, \& Hasbury, 1989; Vandercook, York, \& Forest, 1989). The MAPS process is based on the assumptions of full inclusion, individualization, participation by friends and family, collaboration, and flexibility. The student and people who are most significant in the student's life come together to envision a desirable future for the student. The student's friends and classmates are essential participants. They know the individual in a different way than staff members and family members do. They raise issues of importance, given the student's culture and experience at school, and provide an extensive, creative problem-solving resource. For friends to provide ongoing support to the individual, they must be central in identifying priorities and in designing action plans.

MAPS can be of great benefit to students without disabilities as well, particularly at the secondary level. In fact, student groups could take the lead in facilitating the process and helping one another think about and plan for their respective future lives. Outlined in Figure 8 is the list of questions addressed during the MAPS process and an action planning form. Considerable information on the MAPS process is available (see Forest \& Lusthaus, 1987; O'Brien, Forest, Snow, \& Hasbury, 1989; Vandercook, York, \& Forest, 1989).

All of the student-centered outcomes of Round 3 can be accomplished by using personal future's planning or the MAPS process.

Round 4: Bringing it together and moving forward ... one class at a time. Round 4 brings together the information learned from direct experiences with a student in an inclusive classroom (Round 2) and from envisioning a desirable future (Round 3). By this time, a core group of team members knows the student well enough to make and evaluate individually relevant curricular decisions. The quality of the educational program continues to improve. This final, yet ongoing, round of the curriculum development process has four student-centered outcomes:

Develop a weekly schedule

Identify learning outcomes for each class or learning context

\section{MAPS QUESTIONS}

\section{What is _'s history?}

2. What is your dream for ___ What would be a wonderful future?

Note: For secondary students, break questions into specific areas: home, community, work, relationships.

3. What is your nightmare? What do you want not to happen?

4. What are _'s strengths, gifts and abilities?

5. What do we need to do to realize the dream for

6. What would a "successful" school day look and feel like for 7. What is our plan for this year?

\section{ACTION PLAN}

\begin{tabular}{|l|l|l|l|} 
What has to be done? & Who will do it? & When will it be accomplished? & Follow-up activities \\
\hline
\end{tabular}




\section{$\square$ Determine support needs}

$\square$ Develop, implement, and evaluate instructional strategies

The final round of the process brings together what is known about current participation and what is desired for the future as the basis for deciding where a student should spend his or her time and what learning outcomes are targeted for instruction.

Before developing the weekly schedule, an inventory is conducted of the learning opportunities on and around the school grounds (York \& Vandercook, 1991). The purpose is to identify places and activities in the school community and in the larger community that offer the best chance of preparation for community life. By this point in the curriculum development process, much of this information is already known because of team members' presence in the school. For elementary students, the inventory lists classroom locations and activities and places outside the classroom (e.g., library, media center, playground) and the respective activities in those places. For secondary students, the inventory includes a listing or revisiting of courses available (e.g., course catalog) and surrounding community environments (Falvey, 1989; Ford et al., 1989), in addition to classroom and special-purpose room learning environments (e.g., weight room, media center, computer center, study hall).

With the inventory of possible learning environments in hand, the team decides where a student should spend time throughout the week. Student needs, both current and future, drive these decisions. Suggested criteria for making these decisions include (Bricker \& Campbell, 1980; Browder, 1991; Brown et al., 1988; Meyer \& Evans, 1989; Orelove \& Sobsey, 1991; Rainforth, York, \& Macdonald, 1992):

Increases community membership and participation

Decreases rejection and devaluation

Increases social and communicative interactions with friends and family

Enhances participation in current and future integrated environments

Is of interest to or is preferred by the individual student

Is a family preference

Is of importance to significant others in the environment (e.g., classmates)

Maintains health and vitality

Has frequent or multiple applications across contexts

Is essential for further development

With the outline of a weekly schedule, team members begin the ongoing process of targeting specific learning outcomes for individual students. One way to organize these outcomes is to (a) identify those that will be addressed in many learning contexts throughout the school day; and (b) identify those that are unique to a specific class or other learning context. Figure 9 shows how this information can be summarized for easy review by the team members involved with students.

Class-specific outcomes can be generated using any one of a number of curriculum adaptation processes. Baumgart et al. (1982) proposed several types of adaptations for achieving partial participation in integrated environments:

\section{Utilizing or creating materials or devices \\ $\square$ Adapting skills sequences \\ - Personal assistance \\ Adapting rules \\ 口 Promoting social or attitudinal adaptations}

More recently, and more specific to inclusive classrooms, Giangreco, Cloninger, and Iverson (1992) identified four basic options for participation in any general education setting:

- Same: Participation in the same activities with the same curricular focus and objectives.

- Multi-level: Participation in the same activity or lesson but at a different level (e.g., fewer items in same specific area, lower-level items such as objectives in algebra class related to more basic math skills such as addition or subtraction).

- Curriculum overlapping: Participation in the same activity but with objectives in a different curricular area (e.g., in math class, objectives related to interacting effectively in a small group).

- Alternative: Participation in an alternative activity, targeting outcomes in a different curricular area (e.g., learning to sequence a personal daily schedule during social studies class).

The types of learning opportunities identified early in this article provide a framework for thinking about class-specific learning outcomes as well: learning to be part of a community, learning skills that are useful across contexts, and learning skills specific to the respective curricular area that defines the class period.

After learning targets have been identified, instructional programs are developed. Program development ensures that instruction has been carefully designed, and it provides the basis for evaluation. Are the learning outcomes being accomplished? If not, why? Without a clear understanding of the instructional variables, analysis of what has to change is not possible.

Discussion of a curriculum development process for inclusive classrooms would not be complete without at least minimal attention to support needs. Only after the curricular 


\begin{tabular}{|c|c|c|}
\hline STUDENT: BECKY & \multicolumn{2}{|c|}{ TARGET DATES: SEPTEMBER-NOVEMBER } \\
\hline TARGETS FOR ACROSS THE DAY & MATERIALS & SUPPORT PERSON \\
\hline $\begin{array}{l}\text { 1. Arriving to class on time } \\
\text { 2. Being prepared with necessary materials } \\
\text { 3. Taking out and putting away materials } \\
\text { 4. Greeting peers at various times throughout the day }\end{array}$ & $\begin{array}{l}\text { picture schedule } \\
\text { picture checklist } \\
\text { picture visit }\end{array}$ & $\begin{array}{l}\text { peer } \\
\text { teacher }\end{array}$ \\
\hline TARGET FOR $\frac{\text { READING }}{\text { (class) }}$ & MATERIALS & SUPPORT PERSON \\
\hline $\begin{array}{l}\text { 1. Use headphones } \\
\text { 2. Activate tape recorder } \\
\text { 3. Turn pages to "beep" cue } \\
\text { 4. Select book } \\
\text { 5. Use picture dictionary } \\
\text { 6. Identify one character in story } \\
\text { 7. Retell story }\end{array}$ & $\begin{array}{l}\text { headphones } \\
\text { tape recorder } \\
\text { taped story } \\
\text { picture dictionary } \\
\text { picture sequence cards }\end{array}$ & peer \\
\hline TARGET FOR $\frac{\text { MATH }}{\text { (class) }}$ & MATERIALS & SUPPORT PERSON \\
\hline $\begin{array}{l}\text { 1. Use calculator } \\
\text { 2. Copy information from board to paper } \\
\text { 3. Problem solve with peer } \\
\text { 4. Answer questions in class } \\
\text { 5. Generalize math skills to computer use }\end{array}$ & $\begin{array}{l}\text { calculator } \\
\text { notebook, pencil } \\
\text { computer, software program }\end{array}$ & $\begin{array}{l}\text { peer or paraprofessional } \\
\text { peer or paraprofessional } \\
\text { paraprofessional }\end{array}$ \\
\hline TARGET FOR $\frac{\text { SCIENCE }}{\text { (class) }}$ & MATERIALS & SUPPORT PERSON \\
\hline $\begin{array}{l}\text { 1. Participate in science experiments } \\
\text { 2. Anatomy: identify arms, head, legs in picture of skeleton } \\
\text { 3. Explain the importance of the lungs and circulatory system }\end{array}$ & $\begin{array}{l}\text { skeleton handout, model } \\
\text { diagrams of respiratory } \\
\text { and circulatory systems }\end{array}$ & $\begin{array}{l}\text { peers } \\
\text { peer } \\
\text { peers, teacher }\end{array}$ \\
\hline
\end{tabular}

FIGURE 9

Sample Format for Learning Targets at a Glance

and instructional needs are determined can support decisions can be made. Decisions about people to support the student have to be carefully considered. An additional adult providing support in inclusive classrooms has advantages and disadvantages (York, Vandercook, Heise-Neff, \& Caughey, 1989). Potential advantages include the opportunity to:

- Provide direct instruction to the student

$\square$ Acquire firsthand knowledge of the demands and opportunities in the class, thereby enabling on-the-spot problem solving and insight for curricular and instructional adaptations

- Model and facilitate classmate and general education teacher interaction with the student

$\square$ Establish a positive and supportive relationship with the classroom teacher

- Teach and support all the children in the class

Get to know more about classmates and regular school life in general
Potential disadvantages include:

- Being a physical barrier to interactions with classmates and the classroom teacher

- Conveying implicitly that if assistance is needed, the extra person (as contrasted with natural supports, e.g., classmates, teacher) will provide the assistance

- Hindering the classroom teacher's ownership of the student

Making the teacher uncomfortable by having another adult in the room

Given these advantages and disadvantages, team members need to decide whether an additional adult is necessary or beneficial. Initially, teams may decide that an adult should be added. Many times an additional adult is considered necessary because the curriculum is not yet in place and because the classroom teacher may think he or she cannot meet the needs of student with disabilities. Over time, however, the need for additional adult support usually lessens. 
To take a somewhat broader perspective on the importance of support decisions, consider that if the goal of inclusive community life is to be achieved, community members need to support one another. Today's students will be tomorrow's community members. Classmates are perhaps the greatest untapped resource in our school communities today. Teaching classmates how to support one another and to value each others' unique gifts is beneficial to all.

\section{FINAL THOUGHTS}

Inclusive communities do not simply rise up and happen. Inclusion is not an initiative that can be put into place tomorrow. It is not a curriculum. Perhaps most significantly, it is not a privilege held by a few. An inclusive school community is one in which all members of the community, adults and children, belong. Each community member can be supported by others to maximize individual potential. Inclusive school communities are places where adults and children are committed to the ongoing process of learning and growing together. To be effective, inclusive school communities welcome the continual challenge of identifying the most relevant learning outcomes and most effective learning processes for all students.

Inclusion is much more than a place to go. It is a value to be lived. This curriculum design is one vehicle for working toward inclusive school communities. The strategies presented here will be most effective when general educators, special educators, and other members of the school community join together and discuss how to create schools that embrace the gifts of all students. Clearly, as diversity increases in classrooms and as the needs of today's youth become greater, the old structures and ways of thinking about curriculum will no longer be effective. The challenge we face now is to break out of the old paradigms to allow ourselves to discover new ways of providing the best teaching-learning experiences possible for the children and youth in today's schools.

\footnotetext{
We would like to acknowledge Cathy Macdonald for her assistance during the past four years in developing user-friendly curriculum strategies and tools. We also would like to thank the members of the Institute on Community Integration, Inclusive Education Work Group for their ongoing creativity and support. And a special thank you to the students and staff of the Cambridge and Isanti Middle Schools and other Minnesota school communities who have joined as partners in figuring out how to welcome and support the social and learning needs of all students.
}

\section{REFERENCES}

Ainscow, M. (1991). Effective schools for all. Baltimore: Paul H. Brookes. Baumgart, D., Brown, L., Pumpian, I., Nisbet, J., Ford, A., Sweet, M., Messina, R., \& Schroeder, J. (1982). The principle of partial participation and individualized adaptations in educational programs for stu- dents with severe handicaps. Journal of the Association for Persons with Severe Handicaps, 7(2), 17-27.

Biklen, D. (1992). Schooling without labels. Baltimore: Paul H. Brookes.

Bricker, W., \& Campbell, P. H. (1980). Interdisciplinary assessment and programming for multihandicapped students. In W. Sailor, B. Wilcox, \& L. Brown (Eds.), Methods of instruction for severely handicapped students (pp. 3-45). Baltimore: Paul H. Brookes.

Browder, D. (1991). Assessment of individuals with severe disabilities: An applied behavior approach to life skills assessment (2nd ed.). Baltimore: Paul H. Brookes.

Brown, L., Branston-McLean, M. B., Baumgart D., Vincent, L., Falvey, M., \& Schroeder, J. (1979). Using the characteristics of current and future least restrictive environment in the development of curricular context for severely handicapped students. AAESPH Review, 4(4), 407-424.

Brown, F., Evans, I., Weed, K., \& Owen, V. (1987). Delineating functional competencies. Journal of the Association for Persons with Severe Handicaps, 12, 117-124.

Brown, L., Long, E., Udvari-Solner, A., Davis, L., VanDeventer, P., Ahlgren, C., Johnson, F., Gruenewald, L., \& Jorgensen, J. (1989). The home school: Why students with severe intellectual disabilities must attend the schools of their brothers, sisters, friends and neighbors. Journal of the Association for Persons with Severe Handicaps, 14(1), 1-7.

Brown, L., Long, E., Udvari-Solner, A., Schwartz, P., VanDeventer, P., Ahlgren, C., Johnson, F., Gruenewald, L., \& Jorgensen, J. (1989). Should students with severe intellectual disabilities be based in general or special education classrooms in home schools? Journal of the Association for Persons with Severe Handicaps, 14(1), 8-12.

Brown, L., Shiraga, B., Rogan, P., York, J., Zanella Albright, K., McCarthy, E., Loomis, R., \& VanDeventer, P. (1988). The "why" question in programs for people who are severely intellectually disabled. In S. N. Calculator \& J. L. Bedrosian (Eds.), Communication assessment and intervention for adults with mental retardation (pp. 139-153). Baltimore: Paul H. Brookes.

Davern, L., Gaynor, M., Murphy, M., O’Brien, L., Polly, M. K., Rogers, T., Weber, C., \& Winschell, S. (1990). Transition planning for students in elementary grades: Guidelines for assessing students who need extra support and planning in moving onto the next grade. Syracuse: Inclusive Education Project, Syracuse University.

Falvey, M. (1989). Community-based curriculum: Instructional strategies for students with severe handicaps (2nd ed.). Baltimore: Paul $\mathrm{H}$. Brookes.

Ford, A., Daverr, L., \& Schnorr, R. (1991). Inclusive education: "Making sense" of the curriculum. In S. Stainback \& W. Stainback (Eds.), Curriculum consideration in inclusive classrooms: Facilitating learning for all students. Baltimore: Paul H. Brookes.

Ford, A., Schnorr, R. F., Meyer, L. H., Davern, L., Black, J., \& Dempsey, P. (Eds.). (1989). The Syracuse community-referenced curriculum guide for students with moderate and severe disabilities. Baltimore: Paul H. Brookes.

Forest, M., \& Lusthaus, E. (1987). The kaleidoscope. Challenge to the cascade. In M. Forest (Ed.), More education/integration (pp. 1-16). Downsview, Ontario: G. Allan Roeher Institute.

Giangreco, M. F., Cloninger, C. J., \& Iverson, V. (1992). Choosing options and accommodations for children $(\mathrm{COACH})$ : A planning guide for inclusive education. Baltimore: Paul H. Brookes.

Johnson, D. W., \& Johnson, R. T. (1991). Teaching students to be peacemakers. Edina, MN: Interaction Book Co.

Kohn, A. (1991). Caring kids: The role of the schools. Phi Delta Kappan, 72(7), 496-506.

Kunc, N. (1992). The need to belong: Rediscovering Maslow's hierarchy of needs. In R. Villa, J. Thousand, W. Stainback, \& S. Stainback (Eds.), Restructuring for caring and effective education: An administrative 
guide to creating heterogenous schools (pp. 25-40). Baltimore: Paul H. Brookes.

LeRoy, B., England, J., \& Osbeck, T. (1992). Inclusive school communities: Inclusion planning process. Detroit: Wayne State University, Developmental Disabilities Institute.

Lipsky, D. K., \& Gartner, A. (Eds.).(1989). Beyond separate education: Quality education for all. Baltimore: Paul H. Brookes.

Macdonald, C., \& York, J. (1989). Instruction in regular education classes for students with severe disabilities: Assessment, objectives, and instructional programs. In J. York, T. Vandercook, \& S. Wolff (Eds.), Strategies for full inclusion (pp. 83-116). Minneapolis: University of Minnesota, Institute on Community Integration.

Meyer, L. H., \& Evans, I. M. (1989). Nonaversive intervention for behavior problems: A manual for home and community. Baltimore: Paul $\mathrm{H}$. Brookes.

McDonnell, A., \& Hardman, M. (1989). The desegregation of American schools: Strategies for change. Journal of the Association for Persons with Severe Handicaps, 14(1), 68-74.

Mount, B., \& Zwernik, K. (1988). It's never too early, it's never too late: A booklet about personal futures planning. St. Paul: Metropolitan Council.

O'Brien, J. (1987). A guide to lifestyle planning. In B. Wilcox \& G. T. Bellamy (Eds.), A comprehensive guide to the Activities Catalog. Baltimore: Paul H. Brookes.

O'Brien, J., Forest, M., Snow, J., \& Hasbury, D. (1989). Action for inclusion: How to improve schools by welcoming children with special needs into regular classrooms (Centre for Integrated Education). Toronto, Ontario: Frontier College Press.

O'Brien, J., \& Lyle, C. (1987). Framework for accomplishment. Decatur, GA: Responsive Systems Associates.

Orelove, F. P., \& Sobsey, D. (1991). Educating children with multiple handicaps: A transdisciplinary approach (2nd ed.). Baltimore: Paul $\mathrm{H}$. Brookes.

Rainforth, B., York, J., \& Macdonald, C. (1992). Collaborative teams for students with severe disabilities: Integrating therapy and educational services. Baltimore: Paul H. Brookes.

Sapon-Shevin, M. (1990). Schools as communities of love and care. Holistic Education Review, 3, 22-24.

Schaps, E., \& Solomon, D. (1990). Schools and classrooms as caring communities. Educational Leadership, 48(3), 38-42.

Skrtic, T. M. (1988). The organizational context of special education. In E. L. Meyen and T. M. Skrtic, (Eds.), Exceptional children and youth: An introduction. Denver: Love.
Skrtic, T. M. (1991). Behind special education : A critical analysis of professional culture and school organization. Denver: Love.

Snow, J. A. (1991). Dreaming, speaking and creating: What I know about community. Developmental Disabilities Bulletin, 19(1), 12-27.

Stainback, S., \& Stainback, W. (Eds.). (1991). Curriculum considerations in inclusive classrooms: Facilitating learning for all students. Baltimore: Paul H. Brookes.

Stainback, S., Stainback, W., \& Forest, M. (1989). Educating all students in the mainstream of regular education. Baltimore: Paul H. Brookes.

Taylor, S. J. (1988). Caught in the continuum: A critical analysis of the principles of least restrictive environment. Journal of the Association for Persons with Severe Handicaps, 13(1), 41-53.

Vandercook, T., York, J., \& Forest, M. (1989). The McGill action planning system (MAPS): A strategy for building the vision. Journal of the Association for Persons with Severe Handicaps, 14(3), 205-215.

Wang, M. C. (1992). Adaptive education strategies: Building on diversity. Baltimore: Paul H. Brookes.

Webster's New World Dictionary. (1990). New York: Warner Communications Co.

Will, M. (1986). Educating children with learning problems: A shared responsibility. Washington, DC: U.S. Department of Education, Office of Special Education.

York, J. (1992, Spring). From classroom rules to community expectations. What's working in inclusive education. Minneapolis: University of Minnesota, Institute on Community Integration.

York, J. (1991, Fall). Toward a shared agenda for special and general education. What's working in inclusive education. Minneapolis: University of Minnesota, Institute on Community Integration.

York, J., \& Vandercook, T. (1991). Designing an integrated education through the IEP process. Teaching Exceptional Children, 23(2), 22-28.

York, J., \& Vandercook, T. (1990). Strategies for achieving an integrated education for middle school students with severe disabilities. Remedial and Special Education, 11(5), 6-15.

York, J., Vandercook, T., Heise-Neff, C., \& Caughey, E. (1989, Fall). Does an "integration facilitator" facilitate integration? What's working in integrated education. Minneapolis: University of Minnesota, Institute on Community Integration.

Ysseldyke, J. E., \& Algozzine, B. A. (1990). Introduction to special education. Boston: Houghton Mifflin.

Ysseldyke, J. E., Algozzine, B. A., \& Thurlow, M. (1992). Critical issues in special education (2nd ed.). Boston: Houghton-Mifflin.

\section{PERMISSIONS AND COPYRIGHT}

All rights are reserved. No part of this publication may be reproduced, photocopied, faxed, stored in a retrieval system, or transmitted, in any form or by any means, electronic, mechanical, recording or otherwise, without the prior written permission of the publisher. Back issues are available for sale. Reproduction requires permission and payment of fees. It is illegal and a violation of Federal copyright law to reproduce this publication without permission. Direct all inquiries to the permissions editor. 